\title{
Bioluminescence Single-Site Immunometric Assay for Methamphetamine Using the Photoprotein Aequorin as a Label
}

\author{
Hyun Sook Kim and Insook Rhee Paeng ${ }^{*}$ \\ Department of Chemistry. Seoul Women's University. Seonl 139-774, Korea. "E-mail: irpaeng@asuluac.kr. \\ Received November 8,2005
}

\begin{abstract}
Bioluminescence single-site immunometric assay for methamphetamine (MA) using the native aequorin, a photoprotein, as a signal generator was developed for the first time. $\mathrm{MA}$ is a potent sympathomimetic amine with stimulant effects on the central nervous system. $M \Lambda$ abuse induces hallucinations and, thus, may cause a serious social problem. The single-site immunometric $\mathrm{M} \Lambda$ assay was optimized and its dose-response behavior was examined. The dose-response curve shows that the detection limit is $1.1 \times 10^{-10} \mathrm{M}$ and a dynamic range is four orders of magnitude with $15 \mu \mathrm{g} / \mathrm{mL} \mathrm{BS} \Lambda-\mathrm{M} \Lambda$ conjugate and $1.0 \times 10^{-8} \mathrm{M}$ anti-M antibody-biotin conjugate. In order to evaluate this assay, the structurally similar compounds, amphetamine, ephedrine, norephedrine, benzphetamine and $N$-4-(aminobutyl)methamphetamine were examined for their crossreactivity. None of these five compounds showed any cross-reactivity. $\Lambda$ dditionally, an artificial urine solution spiked with $\mathrm{M \Lambda}$ was analyzed by the $\mathrm{M} \Lambda$ assay, and the result of the analysis demonstrated the usefilness of the present assay for the determination of $\mathrm{M} \Lambda$ in urine.
\end{abstract}

Key Words : Bioluminescence immunoassay, Single-site immunometric assay, Methamphetamine, Aequorin

\section{Introduction}

Immunoassay has emerged as one the most powerful tool with simplicity, specificity and sensitivity in the selective detection of various physiological, biological and environmental substances at trace levels..$^{1-3}$ Luminescence detived from a biological reaction at ordinary temperature is called bioluminescence or "cold light". In contrast to tluorescent and phosphorescent molecules, bioluminescent proteins generate the emission of light on the return to the ground state from an electronically excited species which is produced by a biological reaction. It is not any associated generation of heat, which means it does not need optical excitation. Thus, there is virtually no background signal that degrades sensitivity in assay. Bioluminescent reporter proteins have been used as an excellent label in immunoassay systems due to their advantages of low background, large dynamic range, high sensitivity, and no need of substrate or enhancer. ${ }^{4+6}$

Aequorin is one such luminescent protein. Aequorin is a photoprotein originally found in the jellytish Aequorta Victorta. It has been used extensively as a calcium indicator ${ }^{7}$ and more recently as a highly sensitive quantitative label in analytical assay systems. ${ }^{8-j 0}$ Aequorin consists of the apoaequorin $(22,400 \mathrm{amu})$, coelenterazine (luminophor) and molecular oxygen. When $\mathrm{Ca}^{2}$ binds to the aequorin complex, aequorin undergoes a conformational change, and then coelenterazine is oxidized to coelenteramide, with release of $\mathrm{CO}_{2}$ and light $\left(\lambda_{\mathrm{ntw}} \sim 469 \mathrm{rm}\right){ }^{11}$ The flash-type emission (less than 5 s) of blue light occurs as a singleturnover event.

Methamphetamine (MA) is a potent sympathomimetic amine with stimulant effects on the central nervous system. MA abuse induces hallucinations and, thus, may cause a serious social problem. MA is excreted in urine rapidly and unchanged form of MA (approximately $40 \%$ of the initial dose) is eliminated within the first $24 \mathrm{~h} .^{12}$ Thus, various detection methods ${ }^{1 \hat{*}-15}$ have been developed to test for MA in urine.

Here, a bioluminescence immunoassay is developed for determining MA using aequorin as a label for the first time. A signal-generator should retain a useful residual activity, thus, various aequorin-biotin conjugates were prepared by reacting aequorin with different amounts of NHS-biotin, and the residual activities of each conjugate were characterized. In order to determine the amount of anti-MA antibody to be used in this experiment, a binder dilution study was performed. After evaluating the various parameters such as optimum amount of conjugate, antibody and time, a singlesite immunometric MA assay was optimized and its doseresponse behavior was examined. In order to evaluate this assay, artificial urine solution spiked with MA was analyzed, and structurally similar molecules were examined for their cross-reactivity to determine the specificity of this assay.

\section{Experimental Section}

Reagents. MA, benzphetamine and amphetamine were purchased from Sam Eung Industry (Seoul, Korea). Norephedrine and ephedrine were obtained from Sigma (ST. Louis, MO, USA). Bovine senum albumin (BSA) was purchased from Pierce (Rockford, IL, USA). MA-BSA and monoclonal anti-MA antibody (from mouse) were obtained from Fitzgerald (Concord, MA, USA). Aequorin type III, tris(hydroxymethyl)-aminomethane (Tris) free base, $N$ hydroxysuccinimidobiotin (NHS-Biotin), ethylenediaminetetraacetic acid (EDTA) disodium salt, coelentrazine, sodium azide and Tween 20 were purchased form Sigma 
(ST. Louis, MO, USA). $N$-(4-aminobutyl)methamphetamine was prepared by the literature method. ${ }^{16}$ All chemicals were of analytical-reagent grade or better. All solutions were prepared using deionized (Milli-Q water purification system, Millipore, Bedford, MA, USA) distilled water.

Apparatus. Bioluminescence measurements were made on an MLX-microtiter plate luminometer from Dynex (Chantilly, VA, USA) using a $100 \mu \mathrm{L}$ fixed volume injector. All luminescence intensities reported are the average of at least triplicates and have been corrected for the contribution of the blank. Immuno plate (maxisorp) from Nunc (Denmark) was used.

Preparation of conjugates. Aequorin-biotin conjugate was prepared by reacting aequorin with NHS-biotin (initial molar ratio of aequorin $v$ NHS-biotin was $1: 50$ ). The required amount of NHS-biotin dissolved in anhydrous DMF was added to $1 \mathrm{~mL}$ of coupling buffer $(50 \mathrm{mM}$ sodium bicarbonate buffer, $\mathrm{pH} 8.3$ containing $4 \mathrm{mM}$ EDTA) containing a given amount of aequorin $\left(1.12 \times 10^{-9} \mathrm{~mol}\right)$ and the solution was stirred for $24 \mathrm{~h}$ at $4{ }^{\circ} \mathrm{C}$. The reaction mixture was dialyzed against $30 \mathrm{mM}$ Tris- $\mathrm{HCl}, \mathrm{pH} 7.4$ containing $10 \mathrm{mM}$ EDTA to remove the excess NHS-biotin, and then diluted to a final concentration of $5.6 \times 10^{-2} \mathrm{M}$ aequorin (stock solution of conjugate) with dialysis buffer.

Antibody-biotin conjugates were also prepared by reacting antibody with different amounts of NHS-biotin (initial molar ratios of antibody $v$ s. NHS-biotin were $1: 25,1: 50$ and 1 : 100 , respectively). Here, $6.73 \times 10^{-6} \mathrm{~mol}$ of antibody was used in each coupling solution. The resulting antibody-biotin conjugate was dialyzed against $30 \mathrm{mM}$ phosphate buffer, $\mathrm{pH}$ 7.4 and then diluted to a final concentration of $2.02 \times 10^{-6} \mathrm{M}$ antibody (stock solution of conjugate). All conjugates were kept at $4^{\circ} \mathrm{C}$.

Activity study of aequorin-biotin conjugates. The bioluminescence activity of aequorin-biotin conjugate was determined by measuring the bioluminescence emission at $469 \mathrm{~nm}$. A calibration curve for this aequorin-biotin conjugate was constructed in order to determine the lowest amount of aequorin-biotin conjugates to be used in this study. Serial dilutions of aequorin-biotin solution were made from the aequorin-biotin stock solution using assay buffer-A (30 mM Tris- $\mathrm{HCl}, \mathrm{pH} 7.4$ containing $150 \mathrm{mM} \mathrm{NaCl}, 0.1 \%$ (w/v) BSA, $4 \mathrm{mM}$ EDTA). The calibration curve of aequorin-biotin conjugate was prepared with $100 \mu \mathrm{L}$ of varying concentrations of aequorin-biotin solution in a 96well microlite-1 plate. The contents of the wells were mixed and positioned in the MLX luminometer. And the bioluminescence light was measured after injection of 100 $\mu \mathrm{L}$ of bioluminescence-triggering solution $(100 \mathrm{mM} \mathrm{CaCl} 2$ in $100 \mathrm{mM}$ Tris- $\mathrm{HCl}, \mathrm{pH} 7.5$ ). The emission signal in each well was collected at $0.1 \mathrm{~s}$ interval over a $3 \mathrm{~s}$ time period. A test well containing $100 \mu \mathrm{L}$ of assay buffer-A without aequorin-biotin conjugate was used as a blank.

Optimization of assay conditions (concentrations both of competitor, BSA-MA and antibody-biotin conjugates). In single-site immunometric assay, the detection limit of analyte, MA can be controlled according to the concen- trations both of BSA-MA coated on plate and of antibodybiotin conjugate used. Thus, this assay was optinized by varying concentrations of both.

Association-Time study. For this study, incubation time periods of each step were varied and investigated.

Dose-response curves for MA. By using assay buffer-B (30 $\mathrm{mM}$ sodium phosphate, $\mathrm{pH} 7.4,0.15 \mathrm{M} \mathrm{NaCl}, 0.1 \%$ (w/v) BSA), antibody-biotin and MA standard solutions were prepared. A stock solution of MA standard $\left(5.39 \times 10^{-3}\right.$ M) was serially diluted and prepared as ranging in concentration from $2.0 \times 10^{-\hat{3}} \mathrm{M}$ to $2.0 \times 10^{-1+} \mathrm{M}$. And three differing concentrations of biotinylated monoclonal antibody $\left(6.4 \times 10^{-9} \mathrm{M}, 2.0 \times 10^{-8} \mathrm{M}\right.$ and $\left.2.0 \times 10^{-7} \mathrm{M}\right)$ were prepared. A mixture containing $100 \mu \mathrm{L}$ of each antibodybiotin and $100 \mu \mathrm{L}$ of each MA standard was incubated for 1 $h$ at $R T$ with shaking.

The BSA-MA conjugate was diluted to a concentration of $5 \mu \mathrm{g} / \mathrm{mL}(15 \mu \mathrm{g} / \mathrm{mL})$ with a coating buffer $(50 \mathrm{mM}$ sodium bicarbonate, $\mathrm{pH}$ 9.6). BSA-MA conjugate, $100 \mu \mathrm{L}$, was immobilized on a plate with constant shaking overnight at 4 ${ }^{\circ} \mathrm{C}$. The unbound BSA-MA conjugate was removed by washing with wash buffer-B ( $30 \mathrm{mM}$ sodium phosphate, $\mathrm{pH}$ 7.4, $0.15 \mathrm{M} \mathrm{NaCl}, 0.2 \%(\mathrm{w} / \mathrm{v}) \mathrm{BSA}, 0.05 \%$ Tween 20 ), twice. Then, $100 \mu \mathrm{L}$ of the preliminary arranged mixture, $200 \mu \mathrm{L}$ (containing $100 \mu \mathrm{L}$ of each antibody-biotin and 100 $\mu \mathrm{L}$ of each MA standard) was added to the wells containing the immobilized BSA-MA. The plate was incubated for $1 \mathrm{~h}$ at RT with shaking, and washed twice with wash buffer-B. A solution $(100 \mu \mathrm{L})$ of Avidin $\left(6.46 \times 10^{-6} \mathrm{M}\right)$ in assay bufferA was added to each well and incubation for $1 \mathrm{~h}$ at RT was followed. Unbound avidin was removed by washing with wash buffer-A ( $30 \mathrm{mM}$ Tris- $\mathrm{HCl}, \mathrm{pH} 7.4,0.15 \mathrm{M} \mathrm{NaCl}, 4$ $\mathrm{mM}$ EDTA, $0.2 \%(\mathrm{w} / \mathrm{v}) \mathrm{BSA}$ and $0.05 \%$ Tween 20$)$. A solution $(100 \mu \mathrm{L})$ of aequorin-biotin conjugate $\left(5.6 \times 10^{-9}\right.$ M) in assay buffer-A was added to each well and the plate was additionally incubated for $1 \mathrm{~h}$ at RT. The plate was then washed three times with wash buffer-A, and the bioluminescence intensity was measured after injecting $100 \mu \mathrm{L}$ of the luminescence-triggering solution.

Cross-reactivity study. A cross-reactivity study was accomplished in the same manner as the studies performed for MA in buffer. The compounds structurally similar to MA such as amphetamine, ephedrine, norephedrine, benzphetamine and $N$-(4-aminobutyl)methamphetamine were applied. The percent cross-reactivity was calculated from the dose-response curve for MA.

Matrix effect study. To evaluate the analytical usefulness of this MA assay in urine samples, MA was spiked to 100 $\mu \mathrm{L}$ of artificial urine solution $(1.94 \%$ Urea $/ 0.80 \% \mathrm{NaCl} /$ $0.11 \% \mathrm{MgSO}_{4} \cdot 7 \mathrm{H}_{2} \mathrm{O} / 0.06 \% \mathrm{CaCl}_{-} \%(\mathrm{w} / \mathrm{w})$ ), and the luminescence intensity was measured as described previously.

\section{Results and Discussion}

In heterogeneous assays, signal-generator should retain a useful residual activity. ${ }^{17.18}$ Thus, various aequorin-biotin conjugates were prepared by reacting aequorin with different 
amounts of NHS-biotin. The initial molar ratios of $0: 1,10$; $1,25: 1,50: 1$ and $100: 1$ of NHS-biotin:aequorin were examined and the residual activities of each conjugate were characterized to be $100,98,87,67$ and $0 \%$, respectively (\%residual activity was calculated as percentage of the activity of unconjugated aequorin being considered to be $100 \%$ ). In general, higher initial NHS-biotin/aequorin molar ratios used during the conjugation reaction yielded lower residual activity and greater conjugate inhibition by a given excess of binder. Thus, we decide to use $50: 1$ conjugate based on good bioluminescence activity. Also, $5.6 \times 10^{-9} \mathrm{M}$ of the aequorin-biotin conjugate, $1: 50$ was selected from the calibration study for further studies. A relatively low concentration of protein is capable of generating a signal that is well above the background and thus, achieve a low detection limit. This chemically conjugated aequorin-biotin conjugate shows a flash-type bioluminescence emission with more than $95 \%$ of the total light being emitted within 3 $\mathrm{s}$. Therefore, luminescence light intensity was collected over $3 \mathrm{~s}$ period of time in all subsequent experiments.

Anti-MA antibody-biotin conjugate, $1: 50$ was prepared by similar method as for aequorin-biotin conjugates above by using NHS-biotin. In order to determine the amount of anti-MA antibody to be used in this experiment, a binder dilution study was performed and binder dilution curve obtained by varying the amount of anti-MA antibody. From this study, the linear portion of the binder dilution curve was $10^{-7} \sim 10^{-9} \mathrm{M}$ concentration of anti-MA antibody.

To reduce the total assay time, the optimum times required for bindings of the free MA to the antibody-biotin conjugate, the BSA-MA to the antibody-biotin conjugate, the antibodybiotin conjugate to the avidin, and the avidin to the aequorin- biotin conjugate were detemined by generating each association curve. An association time of $1 \mathrm{~h}$ was selected for each step since there is no substantial increase in binding after 1 h of incubation.

After evaluating the various parameters such as optimum amount of conjugate, antibody and time, several doseresponse curves were constructed using $5.6 \times 10^{-9} \mathrm{M}$ of the aequorin-biotin conjugate, $1: 50$ according to a single-site immunometric assay. A single-site immunometric assay ${ }^{19}$ gives advantages for small chemicals having a few epitope on molecules. Here, sample or standard, MA was first incubated with an anti-MA antibody-biotin conjugate. After the reaction, unbounded anti-MA antibody-biotin conjugate is removed from the solution by the addition to a large excess of solid-phase immobilized BSA-MA, competitor. The solution including standard MA/anti-MA antibodybiotin conjugate was removed off by washing step. Avidin was incubated with anti-MA antibody-biotin immobilized through avidin/biotin interaction on the BSA-MA/anti-MA antibody-biotin coated for $1 \mathrm{~h}$ followed by washing step. And then aequorin-biotin conjugate, $1: 50$ was added to this plate and incubated for additionally $1 \mathrm{~h}$ followed by washing step again. The $\mathrm{Ca}^{2+} /$ Tris luminescence triggering solution was injected into this mixture through fixed volume injector and the resulting luminescence intensity was measured.

Empirically there are two major variants of single-site immunometric assay: One is the antibody in concentrations that are linited. And the other is the competitor, in concentration that is immobilized on the solid surface. Thus, doseresponse curves were constructed with conditions optimized by controlling concentrations of both the competitor $(5 \mu \mathrm{g} /$ $\mathrm{mL}$ and $15 \mu \mathrm{g} / \mathrm{mL})$ and the antibody $\left(1.0 \times 10^{-7} \mathrm{M}, 1.0 \times\right.$

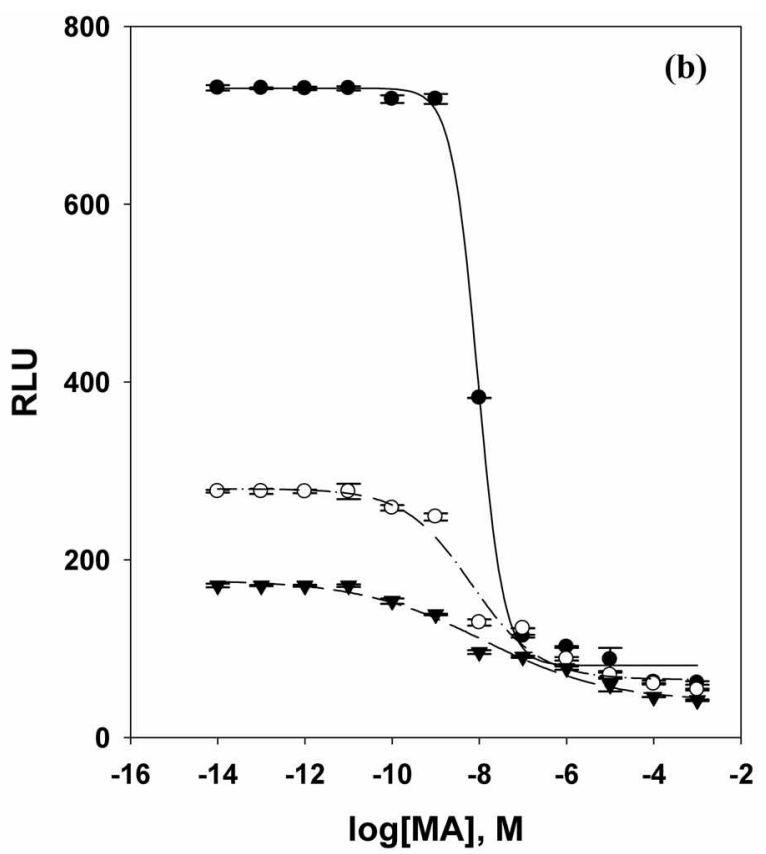

Figure 1. Dose-response curves for MA. The amount of BSA-MA conjugates was: $15.0 \mu \mathrm{g} / \mathrm{mL}$ (a) and $5.0 \mu / \mathrm{mL}$ (b). The amount of

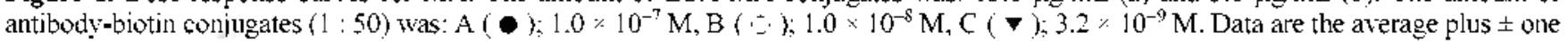
standard deviation $(n=5)$. 

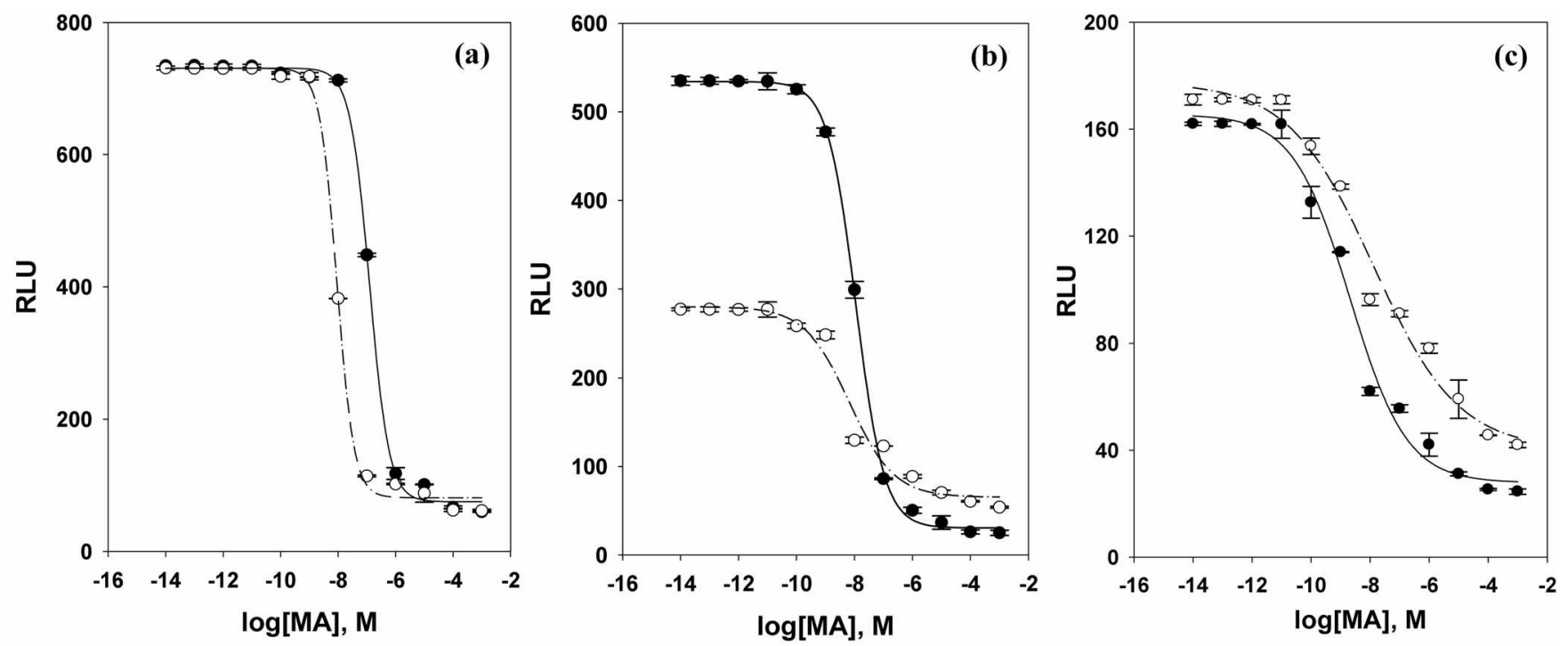

Figure 2. Dose-response curves for MA. The amount of anti-MA antibody-biotin conjugates (1:50) was: $1.0 \times 10^{-7} \mathrm{M}(\mathrm{a}) ; 1.0 \times 10^{-8} \mathrm{M}$ (b) $3.2 \% 10^{-9} \mathrm{M}$ (c). The amount of BSA-MA conjugate was: A ( ) $15.0 \mu \mathrm{g} / \mathrm{mL}, \mathrm{B}(1) ; 5.0 \mu \mathrm{g} / \mathrm{mL}$. Data are the average plus \pm one standard deviation $(n=5)$.

$10^{-8} \mathrm{M}$ and $3.2 \times 10^{-9} \mathrm{M}$ ), and then with plotting luminescence light intensity vs. MA concentration in standards. The dose-response curves were obtained for MA by fixed amounts of $5.6 \times 10^{-9} \mathrm{M}$ aequorim-biotin conjugate, $1: 50$ and $6.46 \times 10^{-6} \mathrm{M}$ Avidin. Figure 1 (a) obtained by using 1.0 $\times 10^{-7} \mathrm{M}, 1.0 \times 10^{-8} \mathrm{M}$ and $3.2 \times 10^{-9} \mathrm{M}$ of anti-MA antibody-biotin conjugate, respectively, with fixed amounts of $15 \mu \mathrm{g} / \mathrm{mL}$ BSA-MA, competitor. The higher concentration of antibody-biotin conjugate is used, the larger signal difference shows on dose-response curve as we expected ( $A$ in Figure 1a). Among these three conditions examined, the dose-response curves show that detection limit is $1 \times 10^{-8} \mathrm{M}$ and a dynamic range is two orders $\left(10^{-8}-10^{-6} \mathrm{M}\right)$ of magnitude with $\mathrm{A}, 1 \times 10^{-10} \mathrm{M}$ and four orders $\left(10^{-10}-10^{-6}\right.$ $\mathrm{M}$ ) of magnitude with $\mathrm{B}$, and $1 \times 10^{-11} \mathrm{M}$ and three orders $\left(10^{-11} \sim 10^{-8} \mathrm{M}\right)$ of magnitude $\mathrm{C}$. Figure 1 (b) also obtained by similar conditions as Figure 1 (a) with fixed amounts of $5 \mu \mathrm{g} /$ mL BSA-MA, competitor. And it shows same trends as Figure 1(a). The detection limits were determined by measuring the signal at 3 times the standard deviation of the blank.

Dose-response (Figure 2(a), 2(b) and 2(c)) curves reconstructed with different coating concentrations of BSA-MA conjugates with same amounts of antibody used. It is examined the intluence of the concentration of competitor in single-site immunometric assay. Figure 2 shows that the detection limit is getting worse with higher concentration of BSA-MA conjugate. In Figure 2(a), the maximum signal has no difference between with $5 \mu \mathrm{g} / \mathrm{mL}$ of competitor and 15 $\mu \mathrm{g} / \mathrm{mL}$ of it. It could be explained that the $5 \mu \mathrm{g} / \mathrm{mL}$ of competitor is an optimized amount to be interacted with given amount of antibody $\left(1 \times 10^{-7} \mathrm{M}\right)$. In the case of Figure 2(c), the signal-difference is only $150 \mathrm{RLU}$ through whole range, the concentration of $10^{-3} \sim 10^{-15} \mathrm{M}$ free-MA. Thus, it is unsuitable as assay-condition.

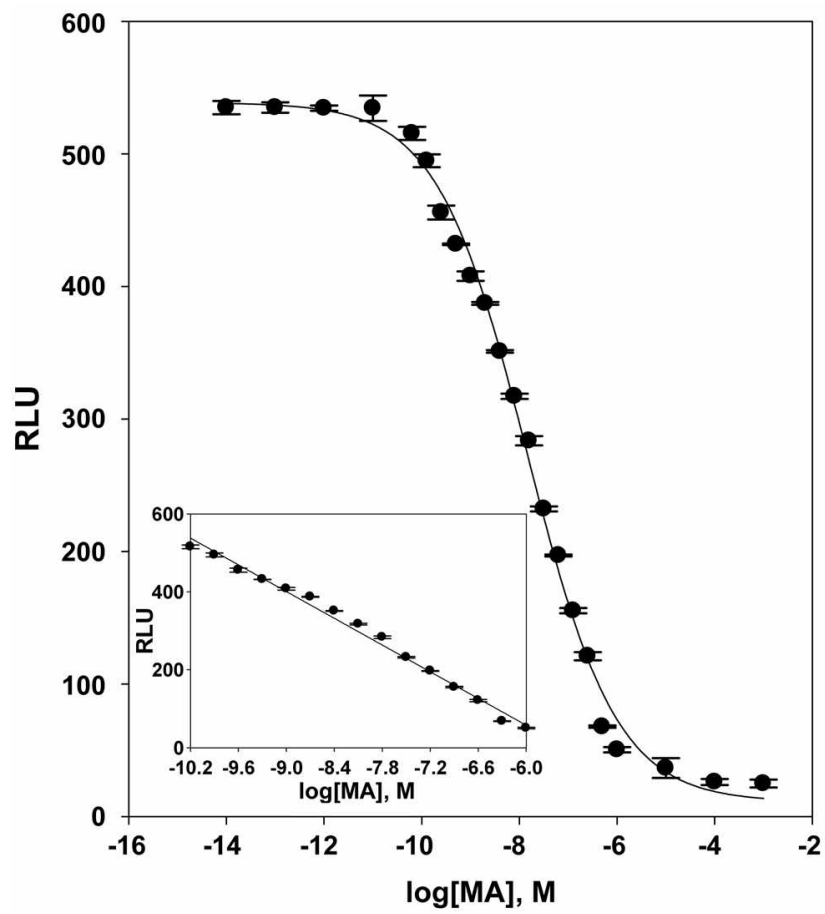

Figure 3. Dose-response curve and calibration curve for MA. 5.6 * $10^{-9} \mathrm{M}$ biotin-aequorin conjugates $(50: 1)$ and $6.46 \times 10^{-6} \mathrm{M}$ avidin were used. $1.0 \times 10^{-8} \mathrm{M}$ antibody-biotin conjugates $(1: 50)$ and $15.0 \mu / \mathrm{mL}$ BSA-MA conjugates were used. RLU $=-114.38 \times$ $\log [\mathrm{MA}]-628.55\left(\mathrm{R}^{2}=0.9907\right)$. Data are the average plus \pm one standard deviation $(n=5)$.

Among these conditions examined, the dose-response curve (Figure 3) shows that the detection limit is $1.1 \times 10^{-19}$ $\mathrm{M}$ and a dynamic range is four orders of magnitude $(1.0 \times$ $10^{-6} \mathrm{M} \sim 1.0 \times 10^{-10} \mathrm{M}$ ) with $15 \mu \mathrm{g} / \mathrm{mL}$ BSA-MA competitor and $1.0 \times 10^{-8} \mathrm{M}$ anti-MA antibody. The correlation plot (inset) of the luminescence light intensity $v$. standard MA 
<smiles>CC(N)Cc1ccccc1</smiles>

Amphetamine<smiles>CC(C(O)c1ccccc1)N(C)C</smiles>

Norephedrine<smiles>CNC(C)C(O)c1ccccc1</smiles>

Ephedrine<smiles>CC(Cc1ccccc1)N(C)c1ccccc1</smiles>

Benzphetamine<smiles>CC(Cc1ccccc1)N(C)CCCCN</smiles>

$\mathrm{N}$-(4-aminobutyl)methamphetamine

Figure 4. Cross-reactants of $\mathrm{M} \Lambda$.

was constructed on dynamic range. Least-squares regression of this data gave the following relationship: RLU $=-114.38$ $\times \log [\mathrm{MA}]-628.55,\left(\mathrm{R}^{2}=0.9907\right)$.

The specificity of the assay is very critical in assay development. ${ }^{20}$ Specificity in immunoassay describes the ability of an antibody to yield a measurable response only for the target molecule and an important part of the evaluation of any immunoanalytical technique, because many drugs (or proteins) have closely related structures with highly conserved epitopes. Thus, the presence of similar structure to the target molecule in the sample solution can reveal the serious errors in results if the assay has poor specificity. Five structurally similar molecules ${ }^{21}$ (Figure 4) to MA, amphetamine, ephedrine, norephedrine, berzphetamine and $\mathrm{N}$-(4-aminobutyl)methamphetamine were examined for their cross-reactivity. Various concentrations of these compounds spiked to aliquots of bufter in the absence of MA. The assay was conducted using $5.6 \times 10^{-9} \mathrm{M}$ aequorin-biotin conjugate, $6.4 \times 10^{-6} \mathrm{M}$ avidin, $1.0 \times 10^{-8} \mathrm{M}$ anti-MA antibody-biotin conjugate and $15 \mu \mathrm{g} / \mathrm{mL}$ BSA-MA conjugate, and then the percent cross-reactivity (Table 1) was determined from the dose-response curve (Figure 5). These results represented that none of these five compounds showed any cross-reactivity with the anti-MA antibody used.

Table 1. Cross-reactivity study

\begin{tabular}{|c|c|c|}
\hline Reactants & $50 \% \mathrm{~B} / \mathrm{B}_{1}$ & $\begin{array}{l}\text { Cross- } \\
\text { reactivity }\end{array}$ \\
\hline Methamphetamine & $1.41: 10^{-8} \mathrm{M}$ & 100.00 \\
\hline Betizphetamine & $8.51 \because 10^{-5} \mathrm{M}$ & $-"$ \\
\hline Amphetamine & $3.55=10^{-5} \mathrm{M}$ & - \\
\hline Ephedrine & $5.13 \div 10^{-1} \mathrm{M}$ & - \\
\hline Norephedritle & $1.86 \because 10^{-3} \mathrm{M}$ & - \\
\hline $\mathrm{N}$-(4-aminobutyl)methamphetamine & $1.66 \cdot 10^{-6} \mathrm{M}$ & - \\
\hline
\end{tabular}

$u \rightarrow$ less than $1 \%$

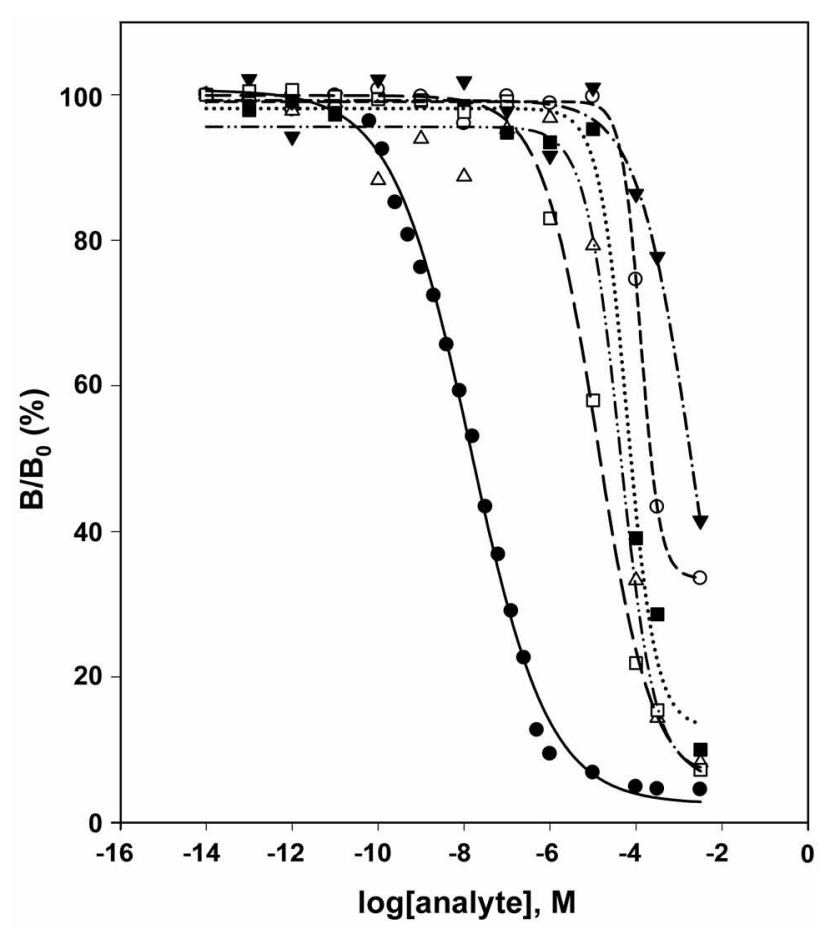

Figurer 5. Cross-reactivity study for cross-reactants. $5.6 \times 10^{-9} \mathrm{M}$ biotin-aequorin conjugates $(50: 1)$ and $6.46 \times 10^{-6} \mathrm{M}$ avidin were used. $1.0 \times 10^{-8} \mathrm{M}$ antibody-biotin conjugates $(1: 50)$ and $15.0 \mu \mathrm{g} /$ inL BS $\Lambda$-M $A$ conjugates were used. $A(\bullet)$ : Methamphetamine; $B$

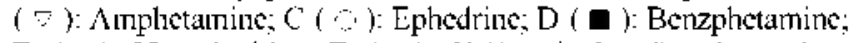
E ( $\mathbf{})$ : Norephedrine; $F(\square): N$-(4-aminobutyl)meth amphetamine.

To demonstrate the usefulness of the present assay for the detemination of $\mathrm{MA}$ in urine, standard amounts of MA corresponding to the detection range were spiked into the each artificial urine solution. Even though this condition isn't exactly same as the real urine samples, it can serve as a good model. The comelation plot of the luminescence light intensity obtained both in buffer and in urine: RLU (in urine) $=1.1304 \times \mathrm{RLU}$ (in buffer $)-0.1116,\left(\mathrm{R}^{2}=0.9954\right)$.

In conclusion, bioluminescence single-site immunometric assay for MA using the native aequorin, a photoprotein, as a signal generator was developed for the first time. A detection limit for MA of $1.1 \times 10^{-10} \mathrm{M}$ was achieved using 15 $\mu \mathrm{g} / \mathrm{mL}$ BSA-MA conjugate and $1.0 \times 10^{-8} \mathrm{M}$ anti-MA antibody-biotin conjugate. Furthermore, no significant crossreactivity was observed from structurally similar compounds to MA. Additionally, an antificial urine solution spiked with MA was analyzed by the MA assay, and the result of the analysis demonstrated the usefulness of the present assay for the determination of MA in urine.

Acknowledgement. This work was supported by Korea Research Foundation Grant (KRF-2002-015-CP0258).

\section{References}

1. Nakanura, R. M.: Kasahara, Y. Inmmochenical Assons and Biosensor Technologn for the 1990's; Rechnitz, G. A., Ed.; 
American Society for Microbiology: Washinglon, DC, U.S.A., 1992.

2. Masseyeff, R. F.: Albert. W. H. Mefhods of Immintological Analyyis; Staines, N. A., Ed.; VCH: New York, L.S.A., 1993; Vols. 1 and 2.

3. Diamandis, E. P. Immumonssor; Diamandis, E. P.; Christopoulos, T. K., Eds.; Academic Press: San Diego, CA., 1996.

4. Shim, Y. N.; Paeng I. R. Anal. Sci. 2001, 17 , a41.

5. Shrestha, S.; Paeng, I. R.: Deo, S. K.: Daunert, S. Bioconjugate Chem. 2002, 13, 269.

6. Shim, Y. N.; Paeng, I. R. Bull. Kor Chem, Soc. 2003, 24(1), 70.

7. George, C. H.; Kendall, J. M.; Campbell, A. K.; Evans, W. H. J. Biol. Chem. 1998, 273(45), 29822.

8. Ramanathan, S.; Lewis, J. C.; Kindy, M. S.; Daunert, S. Anal. Chim Acta 1998, 369(3), 181.

9. Crofcheck, C. L.: Grosvenor, A. L.; Anderson, K. W.: Lumpp, I. K.; Scott, D. L.; Daunert, S. Anth. Chem. 1997, 69:23), 4768.

10. Galvan, B.; Christopoulos, T. K. Anol. Chem, 1996, 68(20), 3545.

11. Prasher, D.; McCann, R. O.; Cornier, M. J. Biochem. Biophys. Res. Commmum. 1985, 126, 1259.

12. Beckett, A. H.; Rowland, M. J. Pharm. Pharmacol, 1965 , $/ 7$,
109 s.

13. Meatherall, R. J. Anal. Toxicol 1995, 19,316.

14. Wang, S.-M.; Giang, Y.-S.; Ling, Y.C. $J$. Chronatogn: $B$ 2001, $759,17$.

15. Mortier, K. A.: Maudens, K. E.: Lambert, W. E.: Clauwaert, K. M.: Van Bocxlaer, J. F.; Deforce, D. L.: Van Peteghem, C. H.; De Leenheer, A. P. J. Clmomatog: $B$ 2002, 779, $32 \mathrm{I}$.

16. Choi, M. J.; Choi, J.; Park, J.; Eremin, S. A. J. of Inmmonoassoy $1995,10(3), 263$.

17. Choi, M. H.; Kin, M. H.; Cho, H. C.; Kim, M. S.; Lee, E. A.; Paeng, I. R.; Cha, G. S. Bull. Kor: Chem. Soc. 2001, 22(4), 417.

18. Paeng, I. R.: Lee, E. A.: Kim, H. S. Buhl. Kor Chem. Soc. 2004, $2.5(1), 115$.

19. Davies, C. The Immmonassan Handbook; Wild, D., Ed.; Nature Publishing group: London, United Kingdom, 2001.

20. Datta, P.; Xu, L.; Malik, S.; Landicho, D.; Ferreri, L.; Halverson, K.: Roby, P. V.: Zebelman, A. M.; Kenny, M. A. Clin. Chem. $1996,42(3), 373$.

2I. Choi, J.: Choi, M. J.: Kim, C.; Cho, Y.S.; Chin, J.: Jo, Y.-A. Arch Phorm. Res. 1997, 20(1), 46. 